Article

\title{
Antimicrobial and Larvicidal Activities of Different Ocimum Essential Oils Extracted by Ultrasound-Assisted Hydrodistillation
}

Kuzhimbattil Sneha ${ }^{1}$, Arunaksharan Narayanankutty ${ }^{1, * \mathbb{D}}$, Joice Tom Job ${ }^{1}$, Opeyemi Joshua Olatunji ${ }^{2, *}$, Ahmed Alfarhan ${ }^{3}$, Ademola C. Famurewa ${ }^{4}$ and Varsha Ramesh ${ }^{5}$

Citation: Sneha, K.; Narayanankutty, A.; Job, J.T.; Olatunji, O.J.; Alfarhan,

A.; Famurewa, A.C.; Ramesh, V.

Antimicrobial and Larvicidal Activities of Different Ocimum Essential Oils Extracted by

Ultrasound-Assisted

Hydrodistillation. Molecules 2022, 27 , 1456. https://doi.org/10.3390/ molecules27051456

Academic Editors: Eliza Oprea and Carmen Chifiriuc

Received: 24 December 2021

Accepted: 8 February 2022

Published: 22 February 2022

Publisher's Note: MDPI stays neutral with regard to jurisdictional claims in published maps and institutional affiliations.

Copyright: (c) 2022 by the authors Licensee MDPI, Basel, Switzerland. This article is an open access article distributed under the terms and conditions of the Creative Commons Attribution (CC BY) license (https:// creativecommons.org/licenses/by/ $4.0 /)$.
1 Division of Cell and Molecular Biology, PG and Research Department of Zoology, St. Joseph's College (Autonomous), Devagiri, Calicut 673 008, Kerala, India; sneha1999@gmail.com (K.S.); joicetomj@gmail.com (J.T.J.)

2 Traditional Thai Medical Research and Innovation Center, Faculty of Traditional Thai Medicine, Prince of Songkla University, Hat Yai, Songkhla 90110, Thailand

3 Department of Botany and Microbiology, College of Science, King Saud University, P.O. Box 2455, Riyadh 11451, Saudi Arabia; alfarhan@ksu.edu.sa

4 Department of Medical Biochemistry, Faculty of Basic Medical Sciences, College of Medicine, Alex-Ekwueme Federal University, Ndufu-Alike Ikwo, P.M.B. 1010, Abakaliki 482131, Nigeria; ademola.famurewa@funai.edu.ng

5 Department of Biotechnology, Deakin University, Geelong, VIC 3217, Australia; v.ramesh@deakin.edu.au

* Correspondence: arunaksharan1990@gmail.com (A.N.); opeyemi.j@psu.ac.th (O.J.O.); Tel.: +91-9847-7935278 (A.N.); +66-850423155 (O.J.O.)

Abstract: Infectious diseases and their vectors have remained a concern for human population from their historical origin. Microbial pathogens have also emerged as a potent threat to the healthcare systems even in developed countries. Essential oils remain a less explored method for infectious disease control; besides, the ultrasound-assisted extraction (UAE) of essential oil production has emerged as promising source of bioactive volatiles over conventional methods. This study analyzed the possible use of UAE- Essential oils (EOs) from different species of Ocimum plants (Ocimum basilicum (OB), O. gratissimum (OG), O. tenuiflorum (OT), and O. canum (OC)) in the management of microbial pathogens and mosquito larval control. The antibacterial activity was estimated in terms of a disc diffusion assay and minimum inhibitory concentrations against Escherichia coli, Staphylococcus aureus, Pseudomonas aeruginosa, and Salmonella enteritidis. The larvicidal property was found using three important mosquito vectors and the $\mathrm{LC}_{50}$ value was determined. Furthermore, antioxidant and antiinflammatory properties were estimated in terms of radical scavenging activities and the inhibition of lipoxygenase enzyme activity. The EOs exhibited significant DPPH radical scavenging (high in OG), hydrogen-peroxide scavenging $(\mathrm{OB})$ and lipoxygenase inhibition $(\mathrm{OB})$. The antibacterial activity was high in OB and OG $(p<0.05)$ and the larvicidal activity was of higher sensitivity against Aedis and Culex, whereas Armigeres was more resistant. However, no sign of toxicity in the Allium cepa model or non-targeted organism Guppy fishes was observed. Overall, the UAE extracted Ocimum essential oils were found to be effective against various human pathogenic microbial organisms, with $\mathrm{OB}$ and OG being highly active. Likewise, the EOs was also able to induce mortality in the larval forms of various mosquito vectors.

Keywords: Ocimum essential oil; Ultrasound Assisted Extraction; larvicidal property; antibacterial activity; antioxidant activity

\section{Introduction}

Infectious diseases accounts for the greatest number of human and livestock death over the recent years [1]. Increased mortality has been associated with some of these diseases, including Ebola, influenza, pneumonia, and sepsis. Among the various pathogenic 
organisms, the microbial pathogens, especially bacterial diseases are the most important and are known to be associated with the highest mortality [2]. Additionally, the management cost of these microbial diseases is also high with respect to the medical expenses and sanitization expenses [3]. Furthermore, the antibiotic resistance that is emerging in various microbial pathogens enhances the risk of microbial disease-mediated health risks [4]. This has led to the search for novel antimicrobial agents, for which, the essential oils derived from aromatic plants are important drug candidates.

Basil plants (Ocimum sp.) are widely used in various traditional medicinal systems including Ayurveda and Chinese medicines as well as folk medicines. The plants have also been important in various cultural and religious aspects in various countries. The plant has been accredited with innumerable health benefits including detoxifying, anti-inflammatory, hypoglycemic, hypolipidemic, organ-system protective and anticancer effects. Among the different products generated from the plant, the essential oils are the most widely used for commercial, industrial and health promotion.

The industrial uses of the essential oils (EOs) are predominantly dependent on its insect repellent or insecticidal potentials. Studies have indicated that the essential oils extracted from selected Ocimum species are found to be efficient in killing the larvae of different mosquitoes. The EOs from O. basilicum has been attributed to mosquito larvicidal activity against the third instar larvae of common mosquitoes such as Culex tritaeniorhynchus, Aedes albopictus and Anopheles subpictus [5]. Similarly, the EOs from O. gratissimum and O. campechianum were shown to reduce the survival of the larval forms of $A$. aegypti and A. albopictus [6,7]. Further, the larvicidal potential of essential oils from O. sanctum against various mosquito species was detected [8,9]. Essential oils extracted from Ocimum plants are also efficient regulators of microbial populations as it has been reported that the essential oils from O. tenuiflorum [10], O. gratissimum [11], O. campechianum [12], and O. basilicum [13] exert antimicrobial properties against different bacterial, viral and fungal strains. Apart from these, EOs from O. basilicum has been effective against the Acanthoscelides obtectus (been weevil) and Planococcus ficus (grape mealybug) [14,15].

Recent developments in these aspects have indicated that the quantity of volatiles being extracted from the plant, its chemical composition percentage and the biological activities of essential oil isolated by ultrasonic assisted hydrodistillation are higher than those isolated by conventional methods [16]. However, there are no available studies on the properties of Ocimum essential oils isolated by ultrasound-assisted methods. Hence, the present study evaluated the chemical composition of the stress volatiles extracted, and larvicidal activity, anti-microbial properties and biological properties. Furthermore, the environmental safety of these essential oils was also evaluated using Allium cepa model and guppy fishes.

\section{Results}

\subsection{Percentage Composition of Stress Volatiles in the Essential Oils by GCMS Analysis}

The ultrasound-assisted hydrodistillation yielded an oil content of $2.38 \%$ (O. gratissimum), $2.15 \%$ (O. basilicum), 2.41\% (O. canum), and 2.11\% (O. tenuiflorum). The phytochemical profiling of the UAE essential oils extracted from different species of Ocimum plants was evaluated by gas chromatography-mass spectroscopy. Among the different oils, the predominant compounds are listed in Table 1 (complete list of compounds in Supplementary Table S1). In O. canum, thymol, linalool, camphor and p-cymene were the predominant compounds (having a \% composition greater than 10\%). In contrast, eugenol, camphor, and estragole were predominant in the O. tenuiflorum essential oil. Estragole, linalool, and methyl eugenol were predominant in the O. basilicum, whereas, in the O.gratissimum, thymol predominated. 
Table 1. Predominant phytochemicals found in the essential oil isolated from different species of Ocimum (Phytochemicals present at $10 \%$ or more are included in the table. Complete chemical composition of all the essential oils are provided in Supplementary Table S1).

\begin{tabular}{|c|c|c|c|c|c|}
\hline \multirow{2}{*}{ Compound } & \multirow{2}{*}{$\begin{array}{l}\text { Retention } \\
\text { Index }\end{array}$} & \multicolumn{4}{|c|}{$\%$ Composition ${ }^{a}$} \\
\hline & & O. tenuiflorum & O. canum & O. basilicum & O. gratissimum \\
\hline p-Cymene & 1022 & 1.9 & 12.2 & 3.2 & 15.1 \\
\hline Linalool & 1094 & 3.5 & 21.1 & 25.2 & 7.7 \\
\hline Camphor & 1144 & 26.2 & 13.7 & 7.6 & 10.1 \\
\hline Methyl Chavicol & 1194 & 18.0 & 4.9 & 32.1 & 9.3 \\
\hline Thymol & 1287 & 7.2 & 27.7 & 8.4 & 32.8 \\
\hline Eugenol & 1355 & 29.0 & 8.4 & 7.2 & 12.3 \\
\hline Methyl eugenol & 1401 & 2.1 & 3.7 & 12.1 & 5.5 \\
\hline
\end{tabular}

\subsection{In Vitro Biological Assays of Anti-Radical and Anti-Inflammatory Activity}

The anti-radical activity of the $O$. basilicum essential oil was found to be higher against DPPH and hydrogen peroxide (Table 2). Likewise, the scavenging activity against ABTS radicals and FRAP capacity was higher in the O. basilicum and O. gratissimum essential oils compared to other essential oils. The inhibitory effect on inflammatory activity was estimated against lipoxygenase assays and nitric oxide production; the NO scavenging activity was high in O. basilicum, whereas lipoxygenase inhibition was equally high in O. gratissimum and O. basilicum.

Table 2. In vitro antioxidant and anti-inflammatory activities of essential oils isolated from different species of Ocimum plants. The activity was estimated in terms of half-maximal inhibition concentration (IC50 value) in $\mu \mathrm{g} / \mathrm{mL}$.

\begin{tabular}{|c|c|c|c|c|}
\hline \multirow{2}{*}{ Assay } & \multicolumn{4}{|c|}{$\mathrm{IC}_{50}$ Values $(\mu \mathrm{g} / \mathrm{mL})$} \\
\hline & O. canum & O. tenuiflorum & O. basilicum & O. gratissimum \\
\hline DPPH radical scavenging & $37.5 \pm 2.09$ & $52.6 \pm 0.89$ & $30.9 \pm 1.32 *$ & $44.2 \pm 3.26$ \\
\hline Hydrogen peroxide scavenging & $38.2 \pm 1.79$ & $39.4 \pm 2.42$ & $27.4 \pm 2.04 *$ & $32.1 \pm 2.84$ \\
\hline ABTS radical scavenging & $29.3 \pm 1.52$ & $26.3 \pm 1.55$ & $21.3 \pm 2.56^{*}$ & $20.3 \pm 2.11 *$ \\
\hline $\begin{array}{l}\text { Ferric reducing } \\
\text { antioxidant power }\end{array}$ & $98.6 \pm 3.02$ & $121.4 \pm 4.21$ & $79.3 \pm 2.77 *$ & $93.2 \pm 4.29$ \\
\hline Nitric oxide radical scavenging & $78.4 \pm 4.07$ & $94.8 \pm 3.67$ & $70.3 \pm 2.33 *$ & $80.4 \pm 2.12$ \\
\hline Lipoxygenase inhibition assay & $79.3 \pm 3.17$ & $72.4 \pm 2.93$ & $60.3 \pm 3.81 *$ & $59.3 \pm 2.64 *$ \\
\hline
\end{tabular}

*indicate $p<0.05$.

\subsection{Anti-Bacterial Activity}

The antimicrobial activity was estimated as antibacterial potentials; the antibacterial activity of essential oils was estimated in terms of zone of inhibition (in millimeters) in agar-well diffusion assay and also as minimum inhibitory concentration. In the disc diffusion assay, O. gratissimum was the most effective against $S$. aureus and S. enteritidis and $O$. basilicum was most effective against $P$. aeruginosa strains. Against E. coli, both $O$. basilicum and O. gratissimum essential oils were most effective (Figure 1a). Corroborating these results, the minimum inhibitory concentration against these organisms were of a similar pattern, where both O. gratissimum and O. basilicum essential oils intercepted the proliferative ability of different bacteria (Figure 1b). 


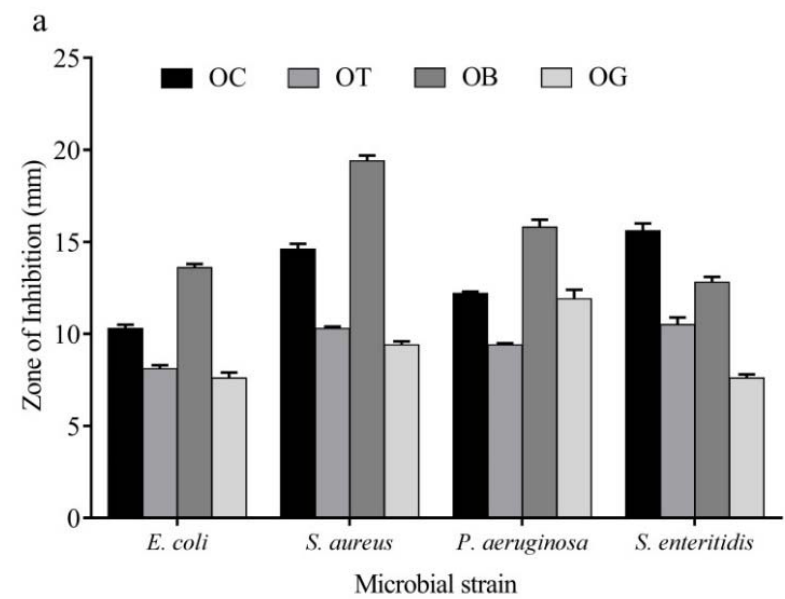

b

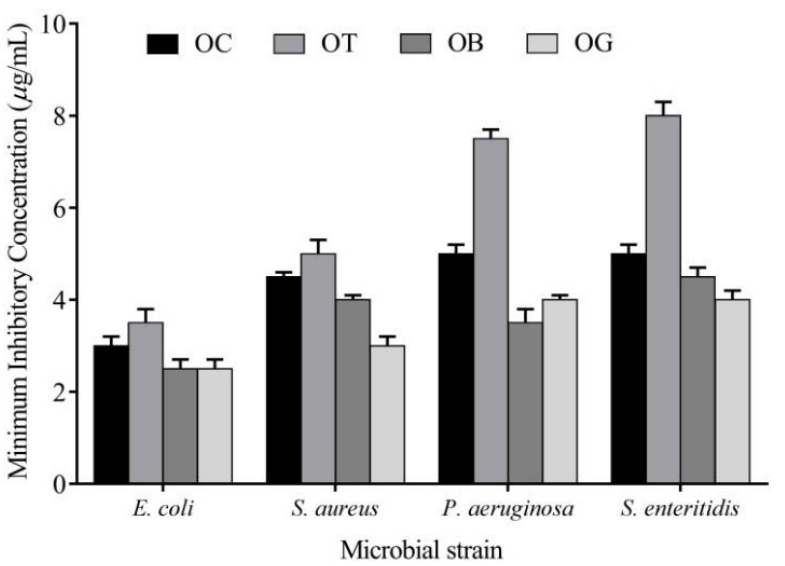

Figure 1. Antibacterial activity of essential oils of different species of Ocimum plants in terms of (a). zone of inhibition $(\mathrm{mm})$ and $(\mathbf{b})$ Minimum inhibitory concentrations $(\mu \mathrm{g} / \mathrm{mL})$.

\subsection{Larvicidal Activity}

The A. aegypti was more sensitive towards O. basilicum and O. gratissimum essential oils, followed by O. canum and O. tenuiflorum. The Culex sp. was sensitive to O. basilicum essential oil. Armigeres subalbatus was the hardy larvae among the different mosquitoes. The sensitivity of the $A$. subalbatus was high against the essential oil of $O$. gratissimum followed by $\mathrm{O}$. basilicum (Figure 2).

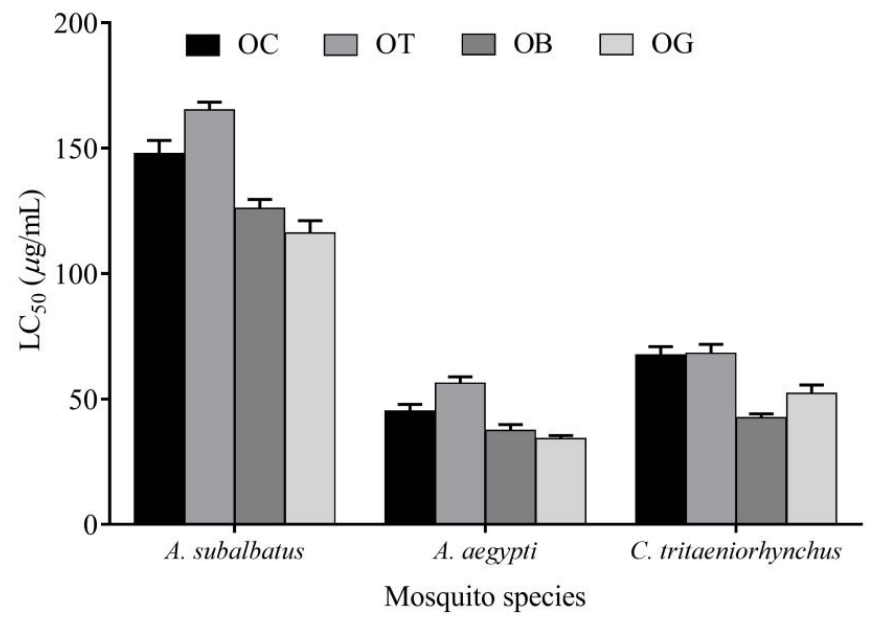

Figure 2. Mosquito larvicidal activity of different Ocimum essential oil and expressed as LC50 value in $\mu \mathrm{g} / \mathrm{mL}$ against different species of mosquito vectors. 


\subsection{Toxicity on Allium Cepa Cells and Non-Targeted Organism}

No significant toxicity or behavioural changes in the guppy fishes were observed until the highest concentrations tested (Supplementary Table S2). All the tested essential oils were found to have no significant behavioural changes indicative of toxicity.

\section{Discussion}

Essential oils are predominantly used in aromatherapy and cosmetic industries. Apart from that, the use of these essential oils as insecticidal compounds is emerging. Essential oils from Ocimum have been the focus of research in the last decade. However, previous studies used the essential oil prepared by steam or hydrodistillation. The present study analyzed the different Ocimum essential oils prepared by ultrasound-assisted hydrodistillation for their beneficial effects. Results indicated a significantly higher yield in the ocimum essential oil by ultrasound assisted methods; previously, it was reported that the yield of essential oil varied between $0.7-2.10 \%$ using classical hydrodistillation methods $[17,18]$. Hence, it is clear that ultrasound assisted hydrodistillation yields of higher quantity of stress volatiles from the selected species of Ocimum plants.

Apart from that, the chemical composition of the stress volatiles (essential oils) also varied from conventional methods of Ocimum essential oil preparation. Previous studies indicated a higher quantity of linalyl acetate and linalool in O. basilicum [19]; O. gratissimum was rich in thymol and eugenol [20]; O. canum contained thymol, p-cymene and $\gamma$-terpinene [21]; whereas $O$. tenuiflorum was rich in eugenol followed by $\beta$-elemene and $\beta$-caryophyllene [22]. The variation in the volatile-compound composition in this essential oil may be attributed to the ultrasound-assisted mode of extraction.

The essential oils also possessed significant antioxidant activity as indicated by the radical scavenging and reducing assays. These free radicals actively participate in the initiation events of oxidative insults to the cellular macromolecules and thereby initiation inflammatory responses in the body. Oxidative insults and subsequent chronic-inflammation are the principal conditions known to be associated with the beginning and end staged of various chronic diseases [23]. The molecules with radical scavenging/reducing potentials can therefore act as chain-breaking antioxidants and may be useful as possible nutraceuticals in the prevention of various degenerative diseases [24]. It is therefore possible that the Ocimum essential oil-derived molecules may emerge as strong chain-breaking antioxidants.

Furthermore, antibacterial activity was also evaluated for the ocimum essential oils prepared by means of ultrasound-assisted methods. Bacteria often pose a threat to the public healthcare systems and professionals due to the multiple diseases they can cause [25]. Therefore, controlling bacterial infections are of high priority in the pharmacology and biomedical research. Due to the origin of multi-drug resistance, search for novel antibiotic compounds have been hastened [26]. The different essential oils, especially from the O. basilicum and O. gratissimum were shown to have significant antibacterial properties and subsequently may emerge as significant antibacterial agents.

Mosquitoes are important vectors of various diseases; therefore, the larvicidal property is of high significance in disease prevention. The essential oils exhibited significant larvicidal properties for the ocimum essential oils against different species of mosquito larvae. Among these, the Aedes aegypti is the most common mosquito vector, which is known to transmit fevers including yellow fever, Zika, dengue, and chikungunya $[27,28]$. Similarly, Culex is also a well-known vector for many other diseases. On the contrary, the Armigeres species is not a common vector; however, it has been reported to transmit filarial worms and zika virus [29-31]. The reports have indicated that the population of A. subalbatus is increasing in various parts of India [32], thereby increasing the risk for various diseases.

Apart from these, the essential oils are generally considered as ecologically safe molecules; hence, they pose very limited environmental issues and health damages. The results from the non-targeted species, guppy fishes, support the assumptions. It is therefore possible that the essential oils of ultrasound-assisted methods may be employed for 
Ocimum essential-oil extraction and which exhibit significant larvicidal, antibacterial and antioxidant properties.

\section{Materials and Methods}

\subsection{Cultivation, Collection and Extraction of Essential Oils from Ocimum Plants}

The authorized and identified plant materials from the nursery were used in the study. The different species of plants including Ocimum basilicum (OB), O. gratissimum $(\mathrm{OG})$, O. tenuiflorum $(\mathrm{OT})$, and $O$. canum $(\mathrm{OC})$ were cultivated in the nursery under normal atmospheric conditions with equal access to water and nutrients. The leaves were collected from these plants under a growth of 3 months. The plants were maintained in cultivation for future use.

The freshly plucked leaves of Ocimum plants (not old, neither tender) were cleaned with cotton, washed with fresh double distilled water and allowed to dry for $30 \mathrm{~min}$ in cloth The leaves were then frozen under ultra-low temperature and grinded with glass mortar and pestle. The powdered leaf material $(10 \mathrm{~g})$ was then mixed with $250 \mathrm{~mL}$ double distilled water in a conical flask and subjected to ultrasound in a Phoenix Ultrasonic Cleaner (SGM Lab solutions, Bangaluru, India) at a frequency of $40 \mathrm{KHz}$ for $30 \mathrm{~min}$ (input power $50 \mathrm{~W}$ ). After $30 \mathrm{~min}$, the samples were further exposed to hydrodistillation using a $300 \mathrm{~mL}$ capacity glass Clevenger-type apparatus (Borosil, India) for $5 \mathrm{~h}$. The extracted essential oils rich in stress volatiles were dried over anhydrous sodium sulphate powder and the purified oil was kept as aliquot in small sample-storage bottles in a refrigerator $\left(4^{\circ} \mathrm{C}\right)$ for future use.

\subsection{GC/MS Analysis of the Stress Volatiles of Different Ocimum Species}

The instrumentation system employed for the GCMS assessment of the essential oils was Thermo Fisher Scientific, Austria; the GC measurement was started after 3 min of sample injection. Furthermore, the temperature of the chromatographic column was sustained at $40^{\circ} \mathrm{C}$ for $3 \mathrm{~min}$, and gradually elevated with a gradient of $8^{\circ} \mathrm{C}$ and temperature of $230^{\circ} \mathrm{C}$ was maintained. For the chromatography, helium was used as the carrier gas set at an automatic flow controller at a rate of $0.5 \mathrm{~mL} / \mathrm{min}$. Mass spectrometric temperature was $200{ }^{\circ} \mathrm{C}$, with a mass range of $20-300 \mathrm{~m} / \mathrm{z}$. The possible stress volatile compounds were derived by comparing the retention indices (RI), retention time (RT), and $\mathrm{m} / \mathrm{z}$ ratio by using the NIST library and comparing the literature reports.

\subsection{In Vitro Biological Properties of Ocimum Essential Oils}

Initially, the essential oil stock was aliquoted into different tubes and preserved under refrigeration; a portion of that was dissolved using $100 \%$ dimethyl sulfoxide to yield a final concentration of $25 \mathrm{mg} / \mathrm{mL}$ and using the stock, further dilutions of the drug were prepared from $0-250 \mu \mathrm{g} / \mathrm{mL}$. The antioxidant property of different essential oils were identified as scavenging of the free radical generators such as DPPH, hydrogen peroxide and ABTS; in addition, the metal reducing potential of the essential oil was determined according to the methods described by Shahinuzzaman [33]. Inhibition of inflammatory enzyme 1-Lipoxygenase was conducted according to the standard protocols described in the studies of Ben-Nasr [34]. Likewise, the scavenging of Nitric oxide radicals formed were determined according the protocols described by Kakatum [35].

\subsection{Antibacterial Activity Assay}

The potential of different essential oils of Ocimum plants as antibacterial agents were determined by disc diffusion method [36]. The different essential oils $(10 \mu \mathrm{L})$ were added to Whatman No.1 filter paper discs of $6 \mathrm{~mm}$ diameter and immersed in agarose plates containing $100 \mu \mathrm{L}$ of different bacterial inoculum (107 CFU/mL). Methanol was used as negative control and streptomycin $(20 \mu \mathrm{g} / \mathrm{disc})$ as positive control. These agarose plates were kept in an incubator for $24 \mathrm{~h}$ at $37^{\circ} \mathrm{C}$. The experiment was repeated thrice, each conducted in duplicate and the zone of inhibition was measured in terms of diameter against each tested bacteria. 


\subsection{Determination of Minimum Inhibitory Concentration (MIC)}

The determination of MIC was performed according the standard protocols described by Standard methods [37]. The bacterial cultures were maintained in the log phase of growth, and a loop of cells were transferred to lactose bile broth and incubated at $37{ }^{\circ} \mathrm{C}$ for $24 \mathrm{~h}$ in a bacteriological incubator. The bacterial density was set to $107 \mathrm{CFU} / \mathrm{mL}$ by spectrophotometric determination at $600 \mathrm{~nm}$ using appropriate dilution using fresh LB broth. Furthermore, $25 \mu \mathrm{L}$ of the inoculum was then added to microplates containing different concentrations of ocimum essential oils (0-10 mg/mL) and incubated for $24 \mathrm{~h}$. The MIC was estimated in terms of the lowest concentration of Ocimum essential oil which had no visible growth after an incubation period of $24 \mathrm{~h}$.

\subsection{Larvicidal Activity against Different Species of Mosquito Larvae}

The cultures of Armigeres subalbatus, Aedes aegypti, and Culex tritaeniorhynchus were maintained for 10 generations. The third instar larvae (50 Nos) was collected from the colony and placed in a $50 \mathrm{~mL}$ beaker and various concentrations of UAE Ocimum essential oils were added by dissolving in DMSO $(0.5 \mathrm{~mL})$ up to $50 \mathrm{~mL}$ using deionized distilled water/milliQ water.

The mortality at the end of $24 \mathrm{~h}$ in each concentration of essential oil was determined by counting the dead larvae (using magnifying lens on a colony counter) and percentage of death and LC50 was estimated.

\subsection{Environmental Safety Analysis on Non-Targeted Species Toxicity in Guppy Fish (Poecilia Reticulata)}

The toxicity of non-targeted organism Guppy fish (Poecilia reticulata) was analyzed as per the standard protocols described by Salako [38]. Guppy fishes of average body length, $3.5 \pm 0.3 \mathrm{~cm}$, and a weight of $1.44 \pm 0.23 \mathrm{~g}$ were used for the study. The guppies were exposed to different concentrations of essential oils and then observed for any sign of toxicity or behavioral changes which were recorded immediately and also during 1, 6, 12, 24 and $48 \mathrm{~h}$.

\subsection{Statistical Analysis}

Data of the anti-microbial studies were expressed in the standard format of Mean \pm SD of four independent experiments, and each of them were conducted in triplicate. The in vitro assays were determined in three different experiments, each carried out in triplicate. The statistical meaning of comparison was drawn from a one-way ANOVA followed by Tukey-Kramer multiple comparison post hoc test.

\section{Conclusions}

Essential oils are industrially important compounds isolated from different plants or plant parts. Ultrasound-assisted hydrodistillation yielded a higher quantity of stress volatiles from different species of Ocimum plants with an increased yield of bioactive compounds. Further, the larvicidal, antibacterial and antioxidant activities were considerably higher in these essential oils. Among these essential oils isolated with the aid of ultrasound assisted hydrodistillation, the most active were those of O. gratissimum and O. basilicum. The study thus concludes that ultrasound-assisted hydrodistillation of Ocimum yields a high quality and quantity of essential oils which may have further industrial applications.

Supplementary Materials: The following are available online. Table S1: Changes in the composition of essential oil isolated from different species of Ocimum analyzed by GC-MS; Supplementary Table S2. The indicators of toxicity in guppy fishes induced by the different Ocimum essential oils. 
Author Contributions: K.S.: Experimentation, Analysis; Manuscript Draft preparation; A.N.: Study design, Methodology, Analysis, Manuscript Editing; J.T.J.: Experimentation, Analysis; Manuscript Draft preparation; O.J.O. and A.A.: Study Design, Methodology, Fund acquisition, Manuscript editing; A.C.F.: Analysis, Manuscript preparation, Manuscript Editing; V.R.: Study design, Manuscript Editing. All authors have read and agreed to the published version of the manuscript.

Funding: This study was supported by King Saud University, Riyadh, Saudi Arabia through Researchers Supporting Project No: RSP 2022/11. Infrastructural development was supported by DBT-STAR to St. Joseph's College, Devagiri, Calicut.

Institutional Review Board Statement: Not applicable.

Informed Consent Statement: Not applicable.

Data Availability Statement: The data may be shared upon a valid request.

Acknowledgments: The authors acknowledge King Saud University, Riyadh, Saudi Arabia for funding this research through Researchers Supporting Project No: RSP 2022/11. AN acknowledges the DBT-STAR scheme for infrastructural development at St. Joseph's College, Devagiri, Calicut.

Conflicts of Interest: The authors declare no conflict of interest.

Sample Availability: Samples of the compounds are available from the corresponding author. Prepared by ultrasound assisted methods (Data shown is for the highest dose $250 \mu \mathrm{g} / \mathrm{L}$ ).

\begin{abstract}
Abbreviations
Ocimum basilicum (OB), O. gratissimum (OG), O. tenuiflorum (OT), O. canum (OC), Ultrasoundassisted hydrodistillation (UAH), Ferric reducing antioxidant power (FRAP), Nitric oxide (NO), Essential oil (EO).
\end{abstract}

\title{
References
}

1. Wakasugi, M.; Kawamura, K.; Yamamoto, S.; Kazama, J.J.; Narita, I. High mortality rate of infectious diseases in dialysis pa-tients: A comparison with the general population in Japan. Ther. Apher. Dial. 2012, 16, 226-231. [CrossRef] [PubMed]

2. Casadevall, A. Climate change brings the specter of new infectious diseases. J. Clin. Investig. 2019, 130, 553-555. [CrossRef] [PubMed]

3. Thaden, J.T.; Li, Y.; Ruffin, F.; Maskarinec, S.A.; Hill-Rorie, J.M.; Wanda, L.C.; Reed, S.D.; Fowler, V.G., Jr. Increased Costs Associated with Bloodstream Infections Caused by Multidrug-Resistant Gram-Negative Bacteria Are Due Primarily to Patients with Hospital-Acquired Infections. Antimicrob. Agents Chemother. 2017, 61, 01709-01716. [CrossRef] [PubMed]

4. Peterson, E.; Kaur, P. Antibiotic Resistance Mechanisms in Bacteria: Relationships Between Resistance Determinants of Antibiotic Producers, Environmental Bacteria, and Clinical Pathogens. Front. Microbiol. 2018, 9, 2928. [CrossRef]

5. Govindarajan, M.; Sivakumar, R.; Rajeswary, M.; Yogalakshmi, K. Chemical composition and larvicidal activity of essential oil from Ocimum basilicum (L.) against Culex tritaeniorhynchus, Aedes albopictus and Anopheles subpictus (Diptera: Culicidae). Exp. Parasitol. 2013, 134, 7-11. [CrossRef]

6. Sumitha, K.V.; Thoppil, J.E. Larvicidal efficacy and chemical constituents of O. gratissimum L. (Lamiaceae) essential oil against Aedes albopictus Skuse (Diptera: Culicidae). Parasitol. Res. 2015, 115, 673-680. [CrossRef]

7. Scalvenzi, L.; Radice, M.; Toma, L.; Severini, F.; Boccolini, D.; Bella, A.; Guerrini, A.; Tacchini, M.; Sacchetti, G.; Chiurato, M.; et al. Larvicidal activity of Ocimum campechianum, Ocotea quixos and Piper aduncum essential oils against Aedes aegypti. Parasite 2019, 26, 23. [CrossRef]

8. Gbolade, A.A.; Lockwood, G.B. Toxicity ofOcimum sanctumL. Essential oil toAedes aegyptiLarvae and its Chemical Composition. J. Essent. Oil Bear. Plants 2008, 11, 148-153. [CrossRef]

9. Cavalcanti, E.S.B.; De Morais, S.M.; Lima, M.A.A.; Santana, E.W.P. Larvicidal Activity of essential oils from Brazilian plants against Aedes aegypti L. Memórias Do Inst. Oswaldo Cruz 2004, 99, 541-544. [CrossRef]

10. Yamani, H.A.; Pang, E.C.; Mantri, N.; Deighton, M.A. Antimicrobial Activity of Tulsi (Ocimum tenuiflorum) Essential Oil and Their Major Constituents against Three Species of Bacteria. Front. Microbiol. 2016, 7, 681. [CrossRef]

11. Matasyoh, L.G.; Matasyoh, J.C.; Wachira, F.; Kinyua, M.G.; Muigai, A.W.T.; Mukiama, T.K. Antimicrobial activity of essential oils of Ocimum gratissimum 1. from different populations of Kenya. Afr. J. Tradit. Complement. Altern. Med. 2008, 5, 187-193. [CrossRef] [PubMed]

12. Benitez, N.P.; León, E.M.M.; Stashenko, E.E. Eugenol and methyl eugenol chemotypes of essential oil of species Ocimum gratissimum L. and Ocimum campechianum Mill. from Colombia. J. Chromatogr. Sci. 2009, 47, 800-803. [CrossRef] [PubMed] 
13. Ilić, Z.S.; Milenković, L.; Šunić, L.; Tmušić, N.; Mastilović, J.; Kevrešan, Ž.; Stanojević, L.; Danilović, B.; Stanojević, J. Efficiency of Basil Essential Oil Antimicrobial Agents under Different Shading Treatments and Harvest Times. Agronomy 2021, 11, 1574. [CrossRef]

14. Karamaouna, F.; Kimbaris, A.; Michaelakis, A.; Papachristos, D.; Polissiou, M.; Papatsakona, P.; Tsora, E. Insecticidal Activity of Plant Essential Oils Against the Vine Mealybug, Planococcus ficus. J. Insect Sci. 2013, 13, 1-13. [CrossRef] [PubMed]

15. Rodríguez-González, Á.; Álvarez-García, S.; González-López, Ó.; Da Silva, F.; Casquero, P.A. Insecticidal Properties of Ocimum basilicum and Cymbopogon winterianus against Acanthoscelides obtectus, Insect Pest of the Common Bean (Phaseolus vulgaris L.) Insects 2019, 10, 151. [CrossRef]

16. Nora, F.M.D.; Borges, C.D. Ultrasound pretreatment as an alternative to improve essential oils extraction. Ciência Rural 2017, 47, e20170173. [CrossRef]

17. Wogiatzi, E.; Papachatzis, A.; Kalorizou, H.; Chouliara, A.; Chouliaras, N. Evaluation of Essential Oil Yield and Chemical Components of Selected Basil Cultivars. Biotechnol. Biotechnol. Equip. 2011, 25, 2525-2527. [CrossRef]

18. Zheljazkov, V.D.; Callahan, A.; Cantrell, C.L. Yield and oil composition of 38 basil (Ocimum basilicum L.) accessions grown in Mississippi. J. Agric. Food Chem. 2008, 56, 241-245. [CrossRef]

19. Dris, D.; Tine-Djebbar, F.; Bouabida, H.; Soltani, N. Chemical composition and activity of an Ocimum basilicum essential oil on Culex pipiens larvae: Toxicological, biometrical and biochemical aspects. S. Afr. J. Bot. 2017, 113, 362-369. [CrossRef]

20. Ntezurubanza, L.; Scheffer, J.J.; Svendsen, A.B. Composition of the Essential Oil of Ocimum gratissimum Grown in Rwan-da1. Planta Med. 1987, 53, 421-423. [CrossRef]

21. da Silva, V.D.; Almeida-Souza, F.; Teles, A.M.; Neto, P.A.; Mondego-Oliveira, R.; Mendes Filho, N.E.; Taniwaki, N.N.; Abreu-Silva, A.L.; Calabrese, K.d.S.; Mouchrek Filho, V.E. Chemical composition of Ocimum canum Sims. essential oil and the antimi-crobial, antiprotozoal and ultrastructural alterations it induces in Leishmania amazonensis promastigotes. Ind. Crops Prod. 2018, 119, 201-208. [CrossRef]

22. Pino, J.A.; Rosado, A.; Rodriguez, M.; Garcia, D. Composition of the Essential Oil of Ocimum tenuiflorum L. Grown in Cuba. J. Essent. Oil Res. 1998, 10, 437-438. [CrossRef]

23. Halliwell, B. Oxidative stress and neurodegeneration: Where are we now? J. Neurochem. 2006, 97, 1634-1658. [CrossRef] [PubMed]

24. Catapano, A.L.; Barrios, V.; Cicero, A.F.; Pirro, M. Lifestyle interventions and nutraceuticals: Guideline-based approach to cardiovascular disease prevention. Atheroscler. Suppl. 2019, 39. [CrossRef]

25. Doron, S.; Gorbach, S.L. Bacterial Infections: Overview. Int. Encycl. Public Health 2008, 273-282. [CrossRef]

26. Wińska, K.; Mączka, W.; Łyczko, J.; Grabarczyk, M.; Czubaszek, A.; Szumny, A. Essential Oils as Antimicrobial Agents-Myth or Real Alternative? Molecules 2019, 24, 2130. [CrossRef]

27. Souza-Neto, J.A.; Powell, J.R.; Bonizzoni, M. Aedes aegypti vector competence studies: A review. Infect. Genet. Evol. 2019, 67, 191-209. [CrossRef]

28. Powell, J.R. Mosquito-Borne Human Viral Diseases: Why Aedes aegypti? Am. J. Trop. Med. Hyg. 2018, 98, 1563-1565. [CrossRef]

29. Muslim, A.; Fong, M.-Y.; Mahmud, R.; Lau, Y.-L.; Sivanandam, S. Armigeres subalbatus incriminated as a vector of zoonotic Brugia pahangi filariasis in suburban Kuala Lumpur, Peninsular Malaysia. Parasites Vectors 2013, 6, 219-225. [CrossRef]

30. Li, C.-X.; Guo, X.-X.; Deng, Y.-Q.; Liu, Q.-M.; Xing, D.; Sun, A.-J.; Wu, Q.; Dong, Y.-D.; Zhang, Y.-M.; Zhang, H.-D.; et al. Susceptibility of Armigeres subalbatus Coquillett (Diptera: Culicidae) to Zika virus through oral and urine infec-tion. PLoS Negl. Trop. Dis. 2020, 14, e0008450. [CrossRef]

31. Aliota, M.T.; Fuchs, J.F.; Rocheleau, T.A.; Clark, A.K.; Hillyer, J.F.; Chen, C.-C.; Christensen, B.M. Mosquito Transcriptome Profiles and Filarial Worm Susceptibility in Armigeres subalbatus. PLoS Negl. Trop. Dis. 2010, 4, e666. [CrossRef] [PubMed]

32. Manimegalai, K. Studies on the mosquito populations from Coimbatore, Tamil Nadu, India. J. Threat. Taxa 2010, 2, 961-969. [CrossRef]

33. Shahinuzzaman, M.; Yaakob, Z.; Anuar, F.H.; Akhtar, P.; Kadir, N.H.A.; Hasan, A.K.M.; Sobayel, K.; Nour, M.; Sindi, H.; Amin, N.; et al. In vitro antioxidant activity of Ficus carica L. latex from 18 different cultivars. Sci. Rep. 2020, 10, 10852. [CrossRef] [PubMed]

34. Miguel, M.G.C.; Ben-Nasr, S.; Aazza, S.; Mnif, W. Antioxidant and anti-lipoxygenase activities of extracts from different parts of Lavatera cretica L. grown in Algarve (Portugal). Pharmacogn. Mag. 2015, 11, 48-54. [CrossRef] [PubMed]

35. Kakatum, N.; Jaiarree, N.; Makchucit, S.; Itharat, A. Antioxidant and anti-inflammatory activities of Thai medicinal plants in Sahasthara remedy for muscle pain treatment. J. Med. Assoc. Thail. 2012, 95, S120-S126.

36. Hossain, M.A.; Kabir, M.J.; Salehuddin, S.M.; Rahman, S.M.M.; Das, A.K.; Singha, S.K.; Alam, M.K.; Rahman, A. Antibacterial proper-ties of essential oils and methanol extracts of sweet basil Ocimum basilicum occurring in Bangladesh. Pharm. Biol. 2010, 48, 504-511. [CrossRef]

37. European Committee for Antimicrobial Susceptibility Testing (EUCAST) of the European Society of Clinical Microbiology and Infectious Diseases (ESCMID). Determination of minimum inhibitory concentrations (MICs) of antibacterial agents by agar dilution. Clin. Microbiol. Infect. 2000, 6, 509-515. [CrossRef] [PubMed]

38. Salako, A.F.; Amaeze, N.H.; Shobajo, H.M.; Osuala, F.I. Comparative acute toxicity of three pyrethroids (Deltamethrin, cypermethrin and lambda-cyhalothrin) on guppy fish (Poecilia reticulata peters, 1859). Sci. Afr. 2020, 9, e00504. 